\title{
SIGNIFICANCE OF PLASMA ANTIOXIDANTS IN PATHOGENESIS OF DENGUE HAEMORRHAGIC FEVER
}

\author{
Nidhi Narasaria Singh ${ }^{1}$, Ashutosh Kumar Singh ${ }^{2}$
}

${ }_{1}^{1}$ Associate Professor, Department of Paediatrics, MIMS, Barabanki, Uttar Pradesh, India.

${ }^{2}$ Associate Professor, Department of Paediatrics, MIMS, Barabanki, Uttar Pradesh, India.

\section{ABSTRACT}

\section{BACKGROUND}

Dengue is a major cause of morbidity in tropical and sub-tropical regions. It has been shown that there is a relationship between immune and oxidative mechanisms leading to altered immune responses. The role of free radicals in the pathogenesis of dengue fever in children is lacking.

Aim- This study was done with the objective of determining various oxidants and antioxidants and evaluating their role in pathogenesis of severe form of Dengue Fever, Dengue Haemorrhagic Fever.

\section{MATERIALS AND METHODS}

30 patients with Dengue Haemorrhagic Fever (DHF) in the age group of 0 - 16 years, having clinical features of DHF and positive findings in blood test were included in this study. Another 30 age and gender-matched children were included in this study to serve as controls. Levels of plasma MDA, protein carbonyl, nitrite, $\mathrm{H}_{2} \mathrm{O}_{2}$ and MPO activity were estimated by different standard methods. Statistical analysis was done with the help of t-test.

Settings- This study was done in Mayo Institute of Medical Sciences, Lucknow.

Design- A prospective, institution-based study.

\section{RESULTS}

The mean age of presentation of children with DHF was comparable to control values. The mean plasma levels of MDA, protein carbonyl, nitrite, $\mathrm{Cu}, \mathrm{H}_{2} \mathrm{O}_{2}$ and MPO activity were significantly higher in patients with DHF as compared to control values ( $\mathrm{p}<0.05$ each).

\section{CONCLUSION}

It can be concluded that imbalances between prooxidants and antioxidants play a significant role in pathogenesis of children with DHF.

\section{KEY WORDS}

Dengue, Antioxidants.

HOW TO CITE THIS ARTICLE: Singh NN, Singh AK. Significance of plasma antioxidants in pathogenesis of dengue haemorrhagic fever. J. Evolution Med. Dent. Sci. 2018;7(43):4639-4641, DOI: 10.14260/jemds/2018/1035

\section{BACKGROUND}

Dengue is a systemic viral infection, which causes significant disease burden in many tropical and sub-tropical regions all over the world. Approximately, 1 million cases of dengue, a major cause of morbidity in tropical and sub-tropical regions are reported annually to the World Health Organization (WHO). ${ }^{1}$ Dengue is caused by the infection with dengue virus (Serotypes 1 - 4) transmitted by the Aedes aegypti mosquito. ${ }^{2}$ Dengue virus is an RNA virus belonging to the family Flaviviridae. ${ }^{3,4}$ The clinical spectrum of dengue fever ranges from a non-specific afebrile illness, a mild form known as Dengue Haemorrhagic Fever (DHF) and Dengue Shock Syndrome (DSS).5,6 Various studies showed relation of severity of dengue varying according to age, ethnicity, genetic factors, immune status and underlying disease. It also depends on the co-circulation of dengue viral serotypes and reinfection by different dengue viral serotypes. 3,4

'Financial or Other Competing Interest': None.

Submission 04-07-2018, Peer Review 01-10-2018,

Acceptance 09-10-2018, Published 22-10-2018.

Corresponding Author:

Nidhi Narasaria Singh,

2/30, Vinamra Khand,

Lucknow,

Uttar Pradesh, India.

E-mail: ashu.ortho@gmail.com

DOI: $10.14260 / \mathrm{jemds} / 2018 / 1035$

\section{(c) (i) $(9)$}

Various studies about pathogenesis of severity of dengue have been done, among them infection-derived oxidative stress is one of the most important factors associated with severity of dengue. Dengue virus triggers release of proinflammatory cytokines including TNF-alpha leading to immunopathogenesis of dengue disease. ${ }^{7}$ Oxidative stress is an imbalance between pro-oxidants and antioxidants in favour of the pro-oxidants. Various studies about effect of infection-derived oxidative stress and redox imbalance on human and animal cell cultures have been done. Olagnier et $\mathrm{al}^{8}$ have reported that production of NOS and ROS pathways were stimulated by DENV-2 infection of human monocytederived dendritic cells. Activated neutrophils induced a process called respiratory burst, where several Reactive Oxygen Species (ROS) are produced. It is caused by the increasing activity of NADPH oxidase and the releasing of myeloperoxidase (MPO). ${ }^{8,9} \mathrm{NADPH}$ oxidase is involved in the formation of several ROS such as hydrogen peroxide (H2O2), while MPO was involved in the formation of another ROS such as $\mathrm{HOCl}^{10} \mathrm{HOCl}$ leads to chlorinative stress. Both oxidative and chlorinative stress leads to lipid peroxidation. ${ }^{10}$ This process was characterised by the formation of some compounds such as malondialdehyde (MDA). ${ }^{11}$ MDA is an indicator for ROS-induced lipid peroxidation. Our present study aimed to investigate the involvement of oxidative stress by measuring H2O2, MDA, Copper, Nitrite, Protein carbonyl level and MPO activity in the serum of children with DHF. 
MATERIALS AND METHODS

Design and Sampling

Design

Case control study.

\section{Study Period}

Two years.

\section{Sampling Procedure}

30 cases of children (16 males and 14 females) aged upto 16 years, having clinical features of DHF as per World Health Organization (WHO), 1997 guidelines for control and prevention of DHF with positive serology were included in this study. ${ }^{12}$ Dengue infection was confirmed by $\operatorname{IgM} / \operatorname{IgG}$ and NS-1 detection. Another 30 age- and gender-matched children attending the Outpatient Department of General Paediatrics for routine check-up were included to serve as controls following simple random sampling method, of which 18 were males and 12 were females.

\section{Sample Size}

The sample size for the study was taken for convenience.

\section{Inclusion Criteria}

Children aged $<16$ years, having clinical features of DHF based on WHO criteria where informed consent was obtained.

\section{Ethical Issues}

Ethical Clearance was sought from Institutional Ethics Committee. Besides this-

1. Written consent was taken from patients participating in the study.

2. Confidentiality was maintained.

Taking all aseptic precautions, about $10 \mathrm{~mL}$ of blood was drawn by venipuncture from a peripheral vein with a heparinised disposable syringe and transferred to sterile, heparinised, deionised polyethylene vials. Plasma was separated from the blood samples immediately by centrifugation at $2000 \mathrm{rpm}$ for 5 minutes and was stored in separate deionised vials in a deep freezer. Plasma MDA was estimated by thiobarbituric acid test. Protein carbonyl and nitrite were analysed by the methods of Reznick and Packer et al and Moshage et al respectively. Plasma copper concentration was estimated by atomic absorption spectrophotometry.

$\mathrm{H}_{2} \mathrm{O}_{2}$ level was calculated by the FOX2 method. MPO activity was measured spectrophotometrically using oDianisidine (Sigma-Aldrich) and $\mathrm{H}_{2} \mathrm{O}_{2} .{ }^{13}$ In the presence of $\mathrm{H}_{2} \mathrm{O}_{2}$ as oxidising agents, MPO catalyses the oxidation of oDianisidine yielding a brown coloured product, oxidised oDianisidine with a maximum absorbance at $470 \mathrm{~nm}$. One unit (U) of MPO activity was defined as that degrading $1 \mu \mathrm{mol}$ of $\mathrm{H}_{2} \mathrm{O}_{2}$ per minute. ${ }^{14}$

\section{Statistical Analysis}

Data were analysed using SPSS 16.0 software. Student's t-test was applied to the parameters with normal (Gaussian) distribution. Statistical significance was taken as 0.05 $(\mathrm{p}<0.05)$.

\section{RESULTS}

The mean age of presentation of children with DHF was $7.4 \pm$ 4.2 yrs., which was comparable to control values. Among the cases, the mean age of presentation was higher for males, but the difference was not statistically significant.

The plasma MDA, protein carbonyl, nitrite, $\mathrm{H}_{2} \mathrm{O}_{2}$ and $\mathrm{Cu}$ levels in children with DHF was shown in Table 1 . The mean plasma levels of MDA, protein carbonyl, nitrite, $\mathrm{Cu}, \mathrm{H}_{2} \mathrm{O}_{2}$ and MPO activity were significantly higher in patients with DHF as compared to control values ( $p<0.05$ each). The mean values of all the parameters were comparable in male and female cases.

\begin{tabular}{|c|c|c|c|}
\hline \multirow{2}{*}{ Parameters } & Mean \pm SD & P-value \\
\cline { 2 - 3 } & Cases & Control & \\
\hline Nitrite $(\mu \mathrm{mol} / \mathrm{L})$ & $86.6 \pm 10.4$ & $28.34 \pm$ & 0.01 \\
& & 8.44 & \\
\hline $\begin{array}{c}\text { Protein carbonyl } \\
(\mathrm{nmol} / \mathrm{mg})\end{array}$ & $42.26 \pm$ & $22.6 \pm 0.82$ & 0.03 \\
\hline $\mathrm{MDA}(\mu \mathrm{mol} / \mathrm{L})$ & $0.96 \pm 0.12$ & $0.28 \pm 0.08$ & 0.024 \\
\hline $\mathrm{Cu}(\mathrm{mg} / \mathrm{dL})$ & $1.12 \pm 0.08$ & $0.68 \pm 0.12$ & 0.04 \\
\hline $\mathrm{H}_{2} \mathrm{O}_{2}(\mathrm{mM})$ & $76.24 \pm 0.12$ & $28.24 \pm$ & 0.012 \\
\hline $\mathrm{MPO}(\mathrm{U} / \mathrm{I})$ & $0.88 \pm 0.06$ & $0.24 \pm 0.1$ & 0.032 \\
\hline Table 1. Comparison of different Parameters between \\
Cases and Controls \\
\hline \multicolumn{4}{|c}{} \\
\hline
\end{tabular}

\section{DISCUSSION}

An imbalance between the production of Reactive OxygenSpecies (ROS) that can damage cell structures and the body's ability to detoxify these molecules or repair the resulting damage leads to oxidative stress. ${ }^{15}$ Production of reactive oxygen species including oxidising compounds such as superoxide radicals, hydrogen peroxide, hydroxyl radical, lipid peroxides and other related species leads to destruction of cells and tissues. ${ }^{16}$

Various studies have reported high serum levels of MDA in dengue patients in comparison to healthy controls.6,17,18 High serum MDA concentrations in children with DHF than in DF were also reported in many studies along with a positive correlation between serum MDA and TNF- $\alpha$ levels. Gil et al reported high serum MDA concentrations in dengue patients. 19

The increased lipid peroxidation with high concentration of MDA and protein carbonyl may arise from a variety of factors such as enhanced generation of free radicals, reduced level of antioxidants, increased consumption, leakage or destruction of antioxidants, decreased protective capacity including antioxidant enzymes, leakage of electrons from the disrupted mitochondrial electron transport chain and phagocyte recruitment and activation. ${ }^{20}$

The role of nitric oxide in pathophysiology of viral infections have been reported in various studies.20,21 Some studies have reported elevated serum levels of nitric oxide in patients with Dengue Fever (DF) as compared to agematched healthy controls. ${ }^{22,23}$ Trairatvorakul et al reported that serum nitric oxide levels were significantly higher in healthy children than in DF or DHF patients. Blood nitrite and 
nitrate levels are frequently assessed as an index of systemic nitric oxide production.

In this study, the results show that serum concentrations of MDA and protein carbonyl in the severe malaria patients was significantly higher than $(p<0.05)$ that of the control group. Protein carbonyl is a by-product of protein oxidation and as far as it could be reviewed no related studies have been done on it in cases of children with DHF till now. Increased plasma $\mathrm{Cu}$ concentrations in patients with DHF might be the result of the inflammatory response of the host against virus. The plasma MDA, protein carbonyl, copper, MPO, $\mathrm{H}_{2} \mathrm{O}_{2}$ and nitrites were significantly raised in cases with DHF as compared to controls $(p<0.05)$ reflecting the increased oxidative stress in cases as compared to controls. The increased levels of nitrite and copper reflect that these are bifunctional and the levels will be high or low depending upon the role they assume in cases with DHF.

\section{CONCLUSION}

Imbalances between different biochemical parameters are indicative of oxidative damage in children with DHF. However, further studies are required to determine the cause-and-effect relationship and its prognostic value in patients with severe malaria.

\section{REFERENCES}

[1] WHO. Working to overcome the global impact of neglected tropical diseases. First WHO report on neglected tropical diseases. Geneva, Switzerland: World Health Organization 2010.

[2] Laughlin CA, Morens DM, Cassetti MC, et al. Dengue research opportunities in the Americas. J Infect Dis 2012;206(7):1121-7.

[3] Guzman A, Isturiz RE. Update on the global spread of dengue. Int J Antimicrob Agents 2010;36 Suppl 1:S402.

[4] World Health Organization. Dengue: Guidelines for diagnosis, treatment, prevention and control. New Edition. Geneva: WHO Guidelines Approved by the Guidelines Review Committee 2009: p. 147.

[5] Malavige GN, Fernando S, Fernando DJ, et al. Dengue viral infections. Postgrad Med J 2004;80(948):588601.

[6] Soundravally R, Hoti SL, Patil SA, et al. Association between proinflammatory cytokines and lipid peroxidation in patients with severe dengue disease around defervescence. Int J Infect Dis 2014;18:68-72.

[7] Olagnier D, Peri S, Steel C, et al. Cellular oxidative stress response controls the antiviral and apoptotic programs in dengue virus-infected dendritic cells. PLoS Pathog 2014;10(12):e1004566.

[8] Yunanto A, Firdaus RT, Triawanti, et al. Advanced oxidation protein products (AOPPs) of newborn at risk of sepsis as novel parameter for early-onset neonatal sepsis. International Journal of Bioscience, Biochemistry, and Bioinformatics 2014;4(2):90-3.
[9] Metzler KD, Fuchs TA, Nauseef WM, et al. Myeloperoxidase is required for neutrophil extracellular trap formation: implications for innate immunity. Blood 2011;117(3):953-9.

[10] Yunanto A, Firdaus RT, Triawanit, et al. Salivary antioxidative index in newborns at risk of sepsis as novel parameter for early-onset neonatal sepsis. Journal of Medical and Bioengineering 2014;3(1):63-6.

[11] Yunanto A, Iskandar, Suhartono E. In-vitro effects of some antibiotic drugs on saliva thiocyanate and oxidation protein products levels on newborn at risk of sepsis. International Journal of Pharmaceutical and Clinical Research 2016;8 (1):86-9.

[12] Suhartono E, Nijka JA, Anhar VY, et al. Anti-lipid peroxidation activities of three selected fruits juices against cadmium induced liver damage in vitro. Journal of Tropical Life Sciences 2015;5(2):75-9.

[13] WHO. Dengue: Guidelines for diagnosis, treatment, prevention and control. Geneva, Switzerland: World Health Organization 2009.

[14] Rao AM, Anand U, Anand CV. Myeloperoxidase in chronic kidney disease. Indian J Clin Biochem 2011;26(1):28-31.

[15] Scheibmeir HD, Christensen K, Whitaker SH, et al. A review of free radicals and antioxidants for critical care nurses. Intensive Crit Care Nurs 2005;21(1):24-8.

[16] Postma NS, Mommers EC, Eling WM, et al. Oxidative stress in malaria; implications for prevention and therapy. Pharm World Sci 1996;18(4):121-9.

[17] Soundravally R, Sankar P, Bobby Z, et al. Oxidative stress in severe dengue viral infection: association of thrombocytopenia with lipid peroxidation. Platelets 2008;19(6):447-54.

[18] Gil L, Martinez G, Tapanes R, et al. Oxidative stress in adult dengue patients. Am J Trop Med Hyg 2004;71(5):652-7.

[19] Wink DA, Hines HB, Cheng RY, et al. Nitric oxide and redox mechanisms in the immune response. J Leukoc Biol 2011;89(6):873-91.

[20] Chaturvedi UC, Nagar R. Nitric oxide in dengue and dengue haemorrhagic fever: necessity or nuisance? FEMS Immunol Med Microbiol 2009;56(1):9-24.

[21] Levy A, Valero N, Espina LM, et al. Increment of interleukin 6, tumour necrosis factor alpha, nitric oxide, C-reactive protein and apoptosis in dengue. Trans R Soc Trop Med Hyg 2010;104(1):16-23.

[22] Chareonsirisuthigul T, Kalayanarooj S, Ubol S. Dengue virus (DENV) antibody-dependent enhancement of infection upregulates the production of antiinflammatory cytokines, but suppresses anti-DENV free radical and pro-inflammatory cytokine production, in THP-1 cells. J Gen Virol 2007;88(Pt 2):365-75.

[23] Trairatvorakul P, Chongsrisawat V, Ngamvasinont D, et al. Serum nitric oxide in children with dengue infection. Asian Pac J Allergy Immunol 2005;23(23):115-9. 